\title{
VIP/PACAP Signaling as an Alternative Target During Hyperoxic Exposure in Preterm Newborns
}

\author{
Qëndrim THAÇI ${ }^{1,3}$, Shkëlzen REÇICA ${ }^{1}$, Islam KRYEZIU1 ${ }^{1}$, Vadim MITROKHIN ${ }^{2}$, \\ Andre KAMKIN ${ }^{2}$, Ramadan SOPI ${ }^{1}$, Nikola HADZI-PETRUSHEV ${ }^{2}$, Mitko MLADENOV ${ }^{2,3}$ \\ ${ }^{1}$ Department of Premedical Courses, Faculty of Medicine, University of Prishtina, Prishtina, \\ Kosovo, ${ }^{2}$ Department of Fundamental and Applied Physiology, Russian National Research Medical \\ University, Moscow, Russia, ${ }^{3}$ Institute of Biology, Faculty of Natural Science and Mathematics, Ss \\ Cyril and Methodius University, Skopje, North Macedonia
}

Received January 5, 2021

Accepted March 25, 2021

Epub Ahead of Print June 2, 2021

\section{Summary}

The use of oxygen therapy (high doses of oxygen - hyperoxia) in the treatment of premature infants results in their survival. However, it also results in a high incidence of chronic lung disease known as bronchopulmonary dysplasia, a disease in which airway hyper-responsiveness and pulmonary hypertension are well known as consequences. In our previous studies, we have shown that hyperoxia causes airway hyper-reactivity, characterized by an increased constrictive and impaired airway smooth muscle relaxation due to a reduced release of relaxant molecules such as nitric oxide, measured under in vivo and in vitro conditions (extra- and intrapulmonary) airways. In addition, the relaxation pathway of the vasoactive intestinal peptide (VIP) and/or pituitary adenylate cyclase activating peptide (PACAP) is another part of this system that plays an important role in the airway caliber. Peptide, which activates VIP cyclase and pituitary adenylate cyclase, has prolonged airway smooth muscle activity. It has long been known that VIP inhibits airway smooth muscle cell proliferation in a mouse model of asthma, but there is no data about its role in the regulation of airway and tracheal smooth muscle contractility during hyperoxic exposure of preterm newborns.

\section{Key words}

Lung • Bronchopulmonary dysplasia • Hyperoxia • Vasoactive intestinal peptide - Pituitary adenylate cyclase-activating polypeptide • Preterm newborns

\section{Corresponding authors}

Q. Thaçi, Department of Biology, Faculty of Medicine, University of Prishtina, Mother Teresa 5, Prishtina 10000, Kosovo, E-mail: qendrimthaqi214@hotmail.com and M. Mladenov, Institute of Biology, Faculty of Natural Science and Mathematics, Ss Cyril and Methodius University, 1000, Skopje, North Macedonia, e-mail: m.mitko@gmail.com

\section{Bronchopulmonary dysplasia}

Bronchopulmonary dysplasia (BPD) was first described in 1967 by Northway et al. as a chronic lung disease in premature infants, (usually those treated with high oxygen partial pressure), because their alveoli are not enough developed to perform respiration (Jobe and Bancalari 2001, Zoban 2019). Airway hyperresponsiveness and pulmonary hypertension $(\mathrm{PH})$ are well known consequences of BPD (Hershenson et al. 1994). Previous studies have shown that hyperoxia (treatment with high doses of oxygen) causes airway smooth muscle (ASM) hyperreactivity due to the reduced release of relaxant molecules such as nitric oxide (NO), changes in prostaglandin $\mathrm{E}_{2}\left(\mathrm{PGE}_{2}\right)$ levels, etc (Sopi et al. 2012, Stamenkovska et al. 2020). The data published through last few decades indicates that hyperreactivity involves many different molecular signaling mechanisms, among which the non-adrenergic-noncholinergic inhibitory system (iNANC) (Anaid et al. 2007), is one of

PHYSIOLOGICAL RESEARCH • ISSN 1802-9973 (online) - an open access article under the CC BY-NC-ND 4.0 license (c) 2021 Institute of Physiology of the Czech Academy of Sciences, Prague, Czech Republic Fax +420 241062 164, e-mail: physres@fgu.cas.cz, www.biomed.cas.cz/physiolres 
the mainly affected systems. Vasoactive intestinal peptide/pituitary adenylate cyclase-activating polypeptide (VIP/PACAP) relaxation pathway, is considered to be another part of this system and plays an important role in the airway caliber (Ao et al. 2011).

The hyperoxic exposure leads to generation of reactive oxygen species (ROS) in the lungs, such as superoxide radical anion $\left(\mathrm{O}_{2}{ }^{-}\right)$, peroxyl radicals (ROO), and hydroxyl radical ( $\mathrm{HO})$. The non-radical derivatives of molecular oxygen $\left(\mathrm{O}_{2}\right)$, like hydrogen peroxide $\left(\mathrm{H}_{2} \mathrm{O}_{2}\right)$, hypochlorous acid ( $\left.\mathrm{HOCl}\right)$, singlet oxygen $\left({ }^{1} \mathrm{O}_{2}\right)$, and peroxynitrite (ONOO), are all strongly associated with the pathophysiology of BPD (Berkelhamer et al. 2013). Another major risk factor for developing BPD is pneumonia, which occurs when pro-inflammatory cytokines such as tumor necrosis factor alpha (TNF- $\alpha$ ), interleukin 1 beta (IL-1 $\beta$ ), interleukin 6 (IL-6), receptor of chemokine 2 (CXCR2), and interleukin 11 (IL-11), are released in response to prenatal and neonatal trigger factors such as mechanical ventilation (Federico et al. 2007). Many of these pro-inflammatory cytokines have been detected in aspirated fluids of neonates with BPD (Bose et al. 2008).

\section{VIP/PACAP (Vasoactive Intestinal Peptide/Pituitary Adenylate Cyclase- Activating Polypeptide)}

The vasoactive intestinal peptide (VIP), also known as the vasoactive intestinal polypeptide, is a 28-amino acid peptide first isolated from the upper intestine in 1975 by Said and later found in many mammalian organs and tissues including the intestines (Costa and Furness 1983), lungs (Dey et al. 1981), kidneys (Barajas et al. 1983), heart (Weihe and Remecke 1981), skin (Bloom and Polak, 1983), pancreas, suprachiasmatic nuclei of the hypothalamus, and widely distributed in the central and peripheral nervous systems (Said 1986), with approximately two minutes of blood half-life (Henning and Sawmiller 2001). The human VIP gene located in the chromosome $6 q 24$ contains 7 introns and 6 exons, of which 5 are encoded (Hahm and Eidem 1998), whereas this gene in the rat is located in the chromosome 1p11 (Lamperti et al. 1991). VIP belongs to the super-family of structurally related peptide hormones which includes glucagon, glucagon-like peptide (GLP), helodermin, secretin, gastric inhibitory polypeptide (GIP), growth hormone releasing factor (GRF), and ligand II protein-receptors (Umetsu et al. 2011). VIPs may also contain sequences, encoding several additional biological neuroendocrine peptides, including the peptide histidine isoleucine [PHI, in low mammals] (Tatemoto and Mutt 1981), peptide histidine methionine [PHM], the human equivalent of PHI (Itoh 1983), histidine valine peptide [PHV] and C-terminal extended form of the PHI and PHM (Yiangou 1987). PHI, PHM, and PHV presumably perform their biological function through the same receptors as VIP (Fahrenkrug 1993).

The pituitary adenylate cyclase (AC), activating polypeptide (PACAP) was firstly isolated from ovine adrenaline secretion, insulin secretion, and immunosuppression (Arimura and Shioda 1995, Ghatei et al. 1993). Its half-life in human blood ranges between 5 and $10 \mathrm{~min}$ (Mentlein 1999). PACAP in humans is encoded by the ADCYAP1 gene and is located in the chromosome 18p11 (Hosoya et al. 1992). Two types of this peptide have been identified to date: 38 amino acid peptides (PACAP-38) isolated from the sheep

Table 1. The amino acid sequences of VIP/PACAP and its related peptides

\begin{tabular}{lccccccccc}
\hline \multirow{2}{*}{ Peptide } & & \multicolumn{8}{c}{ Amino acid sequence } \\
& $\mathbf{5}$ & $\mathbf{1 0}$ & $\mathbf{1 5}$ & $\mathbf{2 0}$ & $\mathbf{2 5}$ & $\mathbf{3 0}$ & $\mathbf{3 5}$ & $\mathbf{4 0}$ & $\mathbf{4 5}$ \\
\hline VIP & HSDAV & FTDNY & TRIRK & QMAVK & KYLNS & ILN & & & \\
PACAP38 & HSDGI & FTDSY & SRYRK & QMAVK & KYLAA & VLGKR & YKQRV & KNK & \\
PACAP27 & HSDGI & FTDSY & SRYRK & QMAVK & KYLAA & VL & & & \\
PHI & HADGV & FTSDF & SRLLG & QLSAL & KYLES & LI & & & \\
Helodermin & HSDAI & FTOOY & SKLLA & KLALO & KYLAS & ILGSR & TSPPP & & \\
Secretin & HSDGT & FTSEL & SRLRD & SARLQ & RLLQG & LV & & & \\
Glucagon & HSQGT & FTSDY & SKYLD & SRRAQ & DFVQV & LMNT & & & \\
GRF & YADAI & FTNSY & RKVLG & QLSAR & KLLQD & YMSRQ & QGESN & QERGA & RARL \\
GIP & YADGT & TFISD & YSIAM & DKIHO & ODFVN & WLLAO & KGKKN & DVKHN & ITO \\
\hline
\end{tabular}


hypothalamus that stimulates $\mathrm{AC}$ in rat anterior pituitary cells in culture (Miyata et al. 1989) and 27 amino acid peptide (PACAP-27), isolated from the same source (Miyata et al. 1990) (Table 1).

\section{VIP/PACAP receptors in the airways}

The biological effects of VIP and PACAP are mediated by three types of G-protein-coupled receptors (GPCR), VPAC1, VPAC2 and PAC1. VPAC1 and VPAC2 receptors are binding sites for both VIP and PACAP, while PAC1 is a binding site for PACAP only (Laburthe et al. 2002, Ito et al. 2001) (Fig. 1). The G protein receptor family is classified into 3 groups (A, B and $C$ ), generally as 7-pass trans-membrane protein receptors. The VIP/PACAP receptor belongs to group B from the GPCR family, which consists of 437-459 amino acid residues (Ulrich et al. 1998). VPAC1 was the first VIP and PACAP receptor isolated from rat lungs by (Ishihara et al. 1992). VPAC1 is also found in the central nervous system (CNS), predominantly in the cerebral cortex and hippocampus (Ishihara et al. 1992, Usdin et al. 1994), in peripheral tissues including the liver, lungs, intestines (Usdin et al. 1994, Sreedharan et al. 1995), as well as in T lymphocytes (Delgado et al. 1996). VPAC2 is the second receptor to respond to VIP and PACAP, cloned by Harmar and coworkers (1995), from a rat's odor bulb and later confirmed by (Usdin et al. 1994). Messenger RNA encoding the VPAC2 receptor is also found in the central nervous system (CNS), and most commonly in the thalamus and supra chiasmic nucleus, as well as in the lower parts like hippocampus, brainstem, spinal cord, and dorsal root ganglia (Ito et al. 2001). The receptor is also present in many peripheral tissues, including the smooth muscles of the cardiovascular, gastrointestinal, and reproductive system (Adamou et al. 1995, Wei and Mojsov 1996). The PAC1 receptor for the first time was cloned by Pisegna and Wank in 1993, from the acinar pancreatic carcinoma cell line (AR4-2J) in rats, with a much greater ability to bind to PACAP-27 and PACAP-38 in comparison to VIP. The DNA sequences of the related mouse (Hashimoto et al. 1996a), bovine (Miyamoto et al. 1994), human (Ogi et al. 1993) and a series of rat receptors were published independently by several groups of authors (Hashimoto et al. 1993, Svoboda et al. 1993). PAC1 is highly expressed in the CNS, in the olfactory bulb, thalamus, hypothalamus, hippocampus, granular cells of the cerebellum [Hashimoto et al. 1996b, Shioda et al. 1997)] and in a number of peripheral tissues, most commonly in the adrenal medulla (Moller et al. 1996) (Fig. 1).

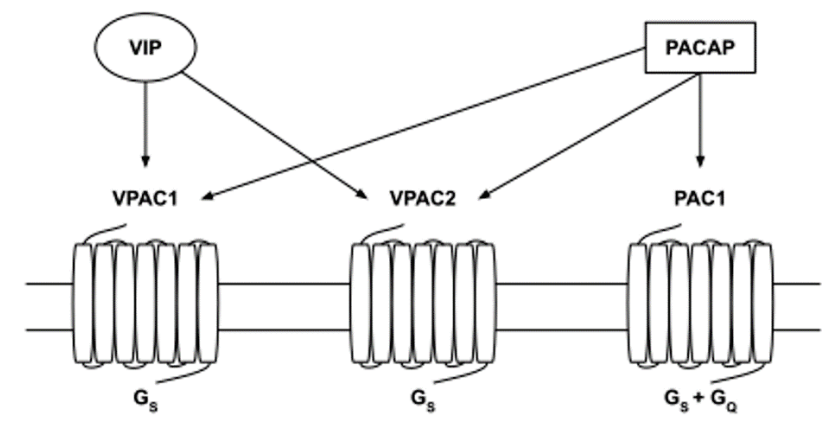

Fig. 1. Schematic representation of the signal transduction pathways of vasoactive intestinal peptide (VIP) / pituitary adenylate cyclase activating polipeptide (PACAP) receptors. Three receptors to PACAP have been described: VPAC1, VPAC2 and PAC1. VIP and PACAP show similar affinity for VPAC1 and VPAC2, whereas PACAP is more selective for PAC1 receptor.

\section{VIP/PACAP signaling pathway in the airways}

High-density VIP and PACAP expressing nerve fibers are found in the tracheobronchial tree, especially in the smooth muscle layer around submucosal, mucousal and serousal glands, in the lamina propria, and the walls of pulmonary and bronchial arteries (Dey et al. 1981). As mentioned before the physiological effects of VIP and PACAP are mediated by three types of G-protein-coupled receptors VPAC1, VPAC2, and PAC1. These physiological actions include relaxation of the airways smooth muscle, bronchodilation (Diamond et al. 1983, Kanazawa et al. 1996), and pulmonary vasodilation (Linden et al. 1999). In different in vivo and in vitro studies, with various subjects including guinea pigs, rabbits, dogs and humans, VIP was shown to cause a reduction of the constrictive effects of histamine, prostaglandin $\mathrm{F}_{2 \alpha}$, kallikrein, leukotriene $\mathrm{D}_{4}$, neurokinins $\mathrm{A}$ and $\mathrm{B}$ and endothelin in isolated tracheal or bronchial segments (Hamasaki et al. 1983, Boomsma et al. 1990). On the other hand, calcium $\left(\mathrm{Ca}^{2+}\right)$ ions as an important player in the mechanisms of the muscle contraction/relaxation processes, may be released by the sarcoplasmic reticulum (SR), or transported from extracellular space (Groneberg et al. 2001, Kuo et al. 2003). After $\mathrm{Ca}^{2+}$ binding to the calmodulin, the myosin light chain kinase (MLCK) activates-(phosphorylate) myosin light chains (MLC), and allows the myosin crossbridge to bind to the actin filaments, leading to contraction (Roux et al. 1997). In relation to VIP/PACAP, it was found that after their binding to corresponding receptors, they causes activation of the membrane-bound AC, which further generates cyclic adenosine monophosphate (cAMP) from adenosine triphosphate (ATP) (Robinson and Colbran 2013, Ganz 
et al. 1986). The intracellular accumulation of cAMP on the level of the airways causes activation of a group of cAMP-dependent protein kinases A (PKA) (Francis et al. 1988, Hedlund et al. 1995). PKA phosphorylates phospholamban (PLN), a protein that normally interferes with the $\mathrm{Ca}^{2+}$ pump within the membrane of the SR. Reducing the level of free cytoplasmic $\mathrm{Ca}^{2+}$ or increasing $\mathrm{Ca}^{2+}$ uptake by internal stores like SR or mitochondria, results with smooth muscle relaxation (Mueller et al. 1979, Somlyo and Somlyo 1994). However, it is important to note that $\mathrm{Ca}^{2+}$ uptake by mitochondria is not cAMP regulated (Borie 1981). Other previous studies in rats, guinea pigs and humans, suggests that cAMP induces relaxation of ASM by interacting with various signaling pathways, including $K^{+}$channels, more likely by membrane hyperpolarisation followed by a reduction in the $\mathrm{Ca}^{2+}$ influx via voltage-dependent $\mathrm{Ca}^{2+}$ channels (Nuttle and Farley 1996, Prakash et al. 1997). In addition, there is evidence that the reduction in the intracellular $\mathrm{Na}^{+}$by the $\mathrm{Na}^{+} / \mathrm{K}^{+}$ATPase, caused increased $\mathrm{Ca}^{2+}$ efflux via $\mathrm{Na}^{+} / \mathrm{Ca}^{2+}$ exchanger, (the exchanger could be activated by PKA or directly by cAMP). The interaction of these channels would therefore be expected to induce ASM relaxation (Hall 2000, McGrogan et al. 1995, Gunst and Strop 1988). Additional mechanisms may contribute to the decreasing in the intracellular $\mathrm{Ca}^{2+}$ concentration, like inositol 1,4,5-triphosphate $\left(\mathrm{IP}_{3}\right)$-gated $\mathrm{Ca}^{2+}$ release channels in the membrane of SR. $\mathrm{IP}_{3}$ plays a substantial role in the opening of these channels, and different studies suggest for PKA prevented formation of the intracellular $\mathrm{IP}_{3}$, consequently followed by a reduced concentration of the intracellular $\mathrm{Ca}^{2+}$ (Yang et al. 1996, Ding et al. 1997). Moreover, activated PKA usually causes MLCK inactivation and reduces its ability to activate the MLCs, which is essential for ASM contraction, and bronchodilatation (Giembicz and Newton 2006).

In addition, VIP is degraded by proteases that are present at/or near the airway mucosa, including mastcell tryptase and chymase and by neutral endopeptidase ("enkephalinase") (Caughey et al. 1988, Goetzl et al. 1989), whereas, PACAP is metabolized by dipeptidyl peptidase IV (Li et al. 2007).

\section{Involvement of the VIP/PACAP signalling in the inflammation}

As indicated before, another major risk factor for the development of BPD is inflammation. Particular types of pro-inflammatory cytokines and chemokines such as
TNF $\alpha$, IL-1 $\beta$, IL-6, chemokine receptor 2 (CXCR2) and CXCL8, IL-11 and IL-12 are related to inflammation. Numerous studies, in animal and human models, showed that VIP/PACAP signaling plays a key role in the balance between pro- and anti-inflammatory factors and possesses essential role in the successful control of inflammation (Gomariz et al. 2006, Ambalavanan et al. 2009). Transcription of the nuclear factor $\kappa \mathrm{B}(\mathrm{NF}-\kappa \mathrm{B})$, leads to increased production of TNF- $\alpha$, IL-1 $\beta$ and IL-6. $\mathrm{VIP} / \mathrm{PACAP}$ on the other hand is able to inhibit NF- $\kappa \mathrm{B}$ translocation through a cAMP independent mechanism, further stimulating production of anti-inflammatory cytokines, such as IL-10, IL-11 and transforming growth factor- $\beta$ (TGF- $\beta$ ), and at the same time prevent inflammation (Delgado et al. 1998, Trepicchio et al. 1996, Tsunawaki et al. 1988, Delgado et al. 1999). The VIP/PACAP cause inhibition of the production of proinflammatory cytokines mainly by involvement of the VPAC1-receptor, and lesser involvement of the VPAC2receptor too (Delgado and Genea 1999, Di Benedetto et al. 2019). The main producers of cytokines are macrophages (Laskin and Pendino 1995, Juarranz et al. 2004). Moreover, VIP/PACAP was found to modulate inflammatory responses by regulation of the different functions in other cells, including the mast cells, microglia, dendritic cells and synovial fibroblasts (Tuncel et al. 2000, Abad et al. 2003). VIP also reduces the proinflammatory $\mathrm{T}$ helper1 (Th1) and T helper 17 (Th17) responses (Delgado et al. 2001, Abad et al. 2011, Benitez et al. 2018, Austin and Loyd 2014).

\section{Involvement of the VIP/PACAP signaling in the} pulmonary hypertension

Another well-known consequence of BPD is pulmonary hypertension (PH), which pathobiology is not yet completely clear. $\mathrm{PH}$ represents high blood pressure in the arteries of the lungs, which occurs when blood vessels in the lungs are narrowed, blocked or destroyed, and as a consequence blood flow through the lungs slows (Lau et al. 2017, Maarman et al. 2017). Other major determinants in the prognosis of the $\mathrm{PH}$, are pulmonary artery pressure greater than $25 \mathrm{mmHg}$ and right ventricular hypertrophy (Maarman et al. 2017). Several abnormal signaling pathways related to the $\mathrm{PH}$ have been identified, including reduced synthesis of prostacyclin and nitric oxide, and increased production of thromboxane and endothelin-1 (Giaida and Saleh 1995, Petkov et al. 2003). The recent studies have focused on the possible implication of the VIP/PACAP system in 
patients with PH. A low level of VIP in the lungs is found in patients suffering from $\mathrm{PH}$ with an over-expression of both types VPAC receptors. Conversely, Said et al. (2007), have shown that VIP inhalation improves hemodynamics and lung capacity in the patients suffering from $\mathrm{PH}$, proposing the peptide as a potential new treatment for $\mathrm{PH}$. Previous observations in mice suggested that genetic knockout of the VIP gene, led to hemodynamic and histomorphological features of arterial $\mathrm{PH}$, whereas intraperitoneal injections of VIP, has been shown to improve vascular pulmonary and right ventricular remodeling (Busto et al. 2000). Same as in other organs and tissues, the effect of VIP/PACAP in human pulmonary artery smooth muscle cells is mediated by VIP receptors VPAC1, VPAC2 and PAC1, which are primarily Gas-coupled receptors (Said et al. 2007). The VPAC2 receptor is highly expressed in human pulmonary artery smooth muscle cells (Said et al. 2007). Gas-coupled receptor activation causes an increase in cAMP, by activating AC, which can increase the activity of downstream mediators such as PKA, or induce expression of the protein directly activated by cAMP. PKA also phosphorylates targets such as MLCK to decrease its activity, resulting with vasodilatation and decreased proliferation of pulmonary artery smooth muscle cells (Fig. 2).

\section{Conclusion}

This review describes the physiological importance of VIP and PACAP in pulmonary diseases including BPD and PH. VIP/PACAP expresses a variety

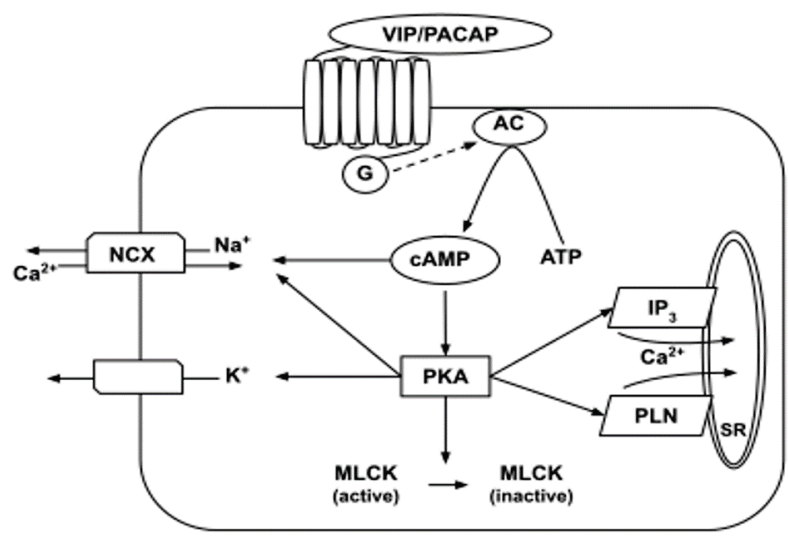

Fig. 2. Molecular actions of VIP/PACAP in induction of relaxation in airway smooth muscle cells. AC- adenylyl cyclase; cAMP cyclic adenosine monophosphate; ATP - adenosine triphosphate; PKA - protein kinases A; IP3 -inositol 1,4,5-triphosphate; PLN phospholamban; MLCK - myosin light chain kinase.

of actions, including potent dilatory actions in the pulmonary blood vessels and ASM and a potent antiinflammatory and anti-proliferative actions. Based on all mentioned above, our opinion is that VIP/PACAP signaling might have an important role in the regulation of airway and tracheal smooth muscle contractility during hyperoxic exposure of preterm newborns. The need for additional investigation may be suggested, that will lead VIP/PACAP or some other player from their airway/tracheal signaling to be classified as a medication in the potential treatment of BPD and PH.

\section{Conflict of Interest}

There is no conflict of interest.

\section{References}

ABAD C, WASCHEK JA. Immunomodulatory roles of VIP and PACAP in models of multiple sclerosis. Curr Pharm Des 17: 1025-1035, 2011. https://doi.org/10.2174/138161211795589364

ABAD C, MARTINEZ C, JUARRANZ MG, ARRANZ A, LECETA J, DELGADO M, GOMARIZ RP: Therapeutic effects of vasoactive intestinal peptide in the trinitrobenzene sulfonic acid mice model of Crohn's disease. Gastroenterology 124: 961-971, 2003. https://doi.org/10.1053/gast.2003.50141

ADAMOU JE, AIYAR N, VAN HORN S, ELSHOURBAGY NA: Cloning and functional characterization of the human vasoactive intestinal peptide (VIP)-2 receptor. Biochem Biophys Res Commun 209: 385-392, 1995. https://doi.org/10.1006/bbrc.1995.1515

AMBALAVANAN N, CARLO WA, D'ANGIO CT, MCDONALD SA, DAS A, SSHENDEL D, THORSEN P, HIGGINS RD; KENNEDY ESH: river National Institute of Child Health and Human Development, Neonatal Research Network. Cytokines associated with bronchopulmonary dysplasia or death in extremely low birth weight infants. Pediatrics 123: 1132-1141, 2009. https://doi.org/10.1542/peds.2008-0526 
ANAID S, PETKOV V, BAYKUSCHEVA-GENTSCHEVA $\mathrm{T}$, HOEGER $\mathrm{H}$, PAINSIPP E, HOLZER P, MOSGOELLER W: Involvement of endothelial NO in the dilator effect of VIP on rat isolated pulmonary artery. Regul Pept 139: 102-108, 2007. https://doi.org/10.1016/j.regpep.2006.10.012

AO X, FANG F, XU F: Role of vasoactive intestinal peptide in hyperoxia-induced injury of primary type II alveolar epithelial cells. Indian J Pediatr 78: 535-539, 2011. https://doi.org/10.1007/s12098-010-0248-1

ARIMURA A, SHIODA S: Pituitary adenylate cyclase activating polypeptide (PACAP) and its receptors: neuroendocrine and endocrine interaction. Front Neuroendocrinol 16: 53-88, 1995. https://doi.org/10.1006/frne.1995.1003

AUSTIN ED, LOYD JE. The genetics of pulmonary arterial hypertension. Circ Res 115: 189-202, 2014. https://doi.org/10.1161/CIRCRESAHA.115.303404

BARAJAS L, SOKOLSKI DN, LECHAGO J: Vasoactive intestinal polypeptide-immunoreactive nerves in the kidney. Neurosci Lett 43: 263-269, 1983. https://doi.org/10.1016/0304-3940(83)90199-4

BENITEZ R, DELGADO-MAROTO V, CARO M, FORTE-LAGO I, DURAN-PRADO M, O'VALLE F, LICHTMAN AH, GONZALEZ-REY E, DELGADO M: Vasoactive intestinal peptide ameliorates acute myocarditis and atherosclerosis by regulating inflammatory and autoimmune responses. J Immunol 200: 3697-3710, 2018. https://doi.org/10.4049/jimmunol.1800122

BERKELHAMER SK, KIM GA, RADDER JE, WEDGWOOD S, CZECH L, STEINHORN RH, SCHUMACKER PT: Developmental differences in hyperoxia-induced oxidative stress and cellular responses in the murine lung. Free Radic Bio Med 61: 51-60, 2013. https://doi.org/10.1016/j.freeradbiomed.2013.03.003

BLOOM SR, POLAK JM: Regulatory peptides and the skin. Clin Exp Dermatol 8: 3-18, 1983. https://doi.org/10.1111/j.1365-2230.1983.tb01738.x

BOOMSMA JD, FODA HD, SAID SI: Vasoactive intestinal peptide (VIP) reverses endothelin-induced contractions of guinea pig trachea and pulmonary artery. Am Rev Respir Dis 141: A485, 1990.

BORIE AB. Control, modulation and regulation of cell calcium. Rev Physiol Biochem Pharmacol 90: 13-153, 1981. https://doi.org/10.1007/BFb0034078

BOSE CL, DAMMANN CEL, LAUGHON MM: Bronchopulmonary dysplasia and inflammatory biomarkers in the premature neonate. Arch Dis Child Fetal Neonatal 93: 455-461, 2008. https://doi.org/10.1136/adc.2007.121327

BUSTO R, PRIETO JC, BODEGA G, ZAPATERO J, CARRERO I: Immunohistochemical localization and distribution of VIP/PACAP receptors in human lung. Peptides 21: 265-269, 2000. https://doi.org/10.1016/S0196-9781(99)00202-8

CAUGHEY GH, LEIDIG F, VIRO NF, NADEL JA: Substance P and vasoactive intestinal peptide degradation by mast cell tryptase and chymase. J Pharmacol Exp Ther 244: 133-137, 1988.

COSTA M, FURNESS JB. The origins, pathways and terminations of neurons with VIP-like immunoreactivity in the guinea-pig small intestine. Neuroscience 8: 665-676, 1983. https://doi.org/10.1016/0306-4522(83)90002-7

DELGADO M, ABAD C, MARTINEZ C, LECETA J, GOMARIZ RP: Vasoactive intestinal peptide prevents experimental arthritis by downregulating both autoimmune and inflammatory components of the disease. Nat Med 7: 563-568, 2001. https://doi.org/10.1038/87887

DELGADO M, MUNOZ-ELIAS EJ, GOMARIZ RP, GANEA D: Vasoactive intestinal peptide and pituitary adenylate cyclase-activating polypeptide enhance IL-10 production by murine macrophages: in vitro and in vivo studies. J Immunol 162: 1707-1716, 1999.

DELGADO M, GENEA D: Vasoactive intestinal peptide and pituitary adenylate cyclase activating polypeptide inhibit IL-12 transcription by regulating NF-KB and Ets activation. J Biol Chem 274: 31930-31940, 1999. https://doi.org/10.1074/jbc.274.45.31930

DELGADO M, MUNOZ-ELIAS EJ, KAN Y, GOZES I, FRIDKIN M, BRENNEMAN DE, GOMARIZ RP, GANEA D: Vasoactive intestinal peptide and pituitary adenylate cyclase-activating polypeptide inhibit tumor necrosis factor alpha transcriptional activation by regulating nuclear factor- $\square \mathrm{B}$ and cAMP response element-binding protein/c-Jun. J Biol Chem 273: 31427-31436, 1998. https://doi.org/10.1074/jbc.273.47.31427

DELGADO M, MARTINEZ C, JOHNSON MC, GOMARIZ RP, GANEA D: Differential expression of vasoactive intestinal peptide receptors 1 and 2 (VIP-R1 and VIP-R2) mRNA in murine lymphocytes. J Neuroimmunol 68: 27-38, 1996. https://doi.org/10.1016/0165-5728(96)00063-X 
DEY RD, SHANNON WA, STUD SI: Localization of VIP-immunoreactlve nerves in airways and pulmonary vessels of dogs, cats and human subjects. Cell Tissue Res 220: 231-238, 1981. https://doi.org/10.1007/BF00210505

DIAMOND L, SZAREK LJ, GILLESPIE MN, ALTIERE RJ: In vivo bronchodilator activity of vasoactive intestinal peptide in the cat. Am Rev Respir Dis 12: 827-832, 1983.

DI BENEDETTO P, RUSCITTI P, VADAS Z, TOUBI E, GIACOMELLI R: Macrophages with regulatory functions, a possible new therapeutic perspective in autoimmune diseases. Autoimmun Rev 18: 102369, 2019. https://doi.org/10.1016/j.autrev.2019.102369

DING KH, HUSAIN S, AKHTAR RA, ISALES CM, ABDEL-LATIF AA: Inhibition of muscarinic-stimulated polyphosphoinositide hydrolysis and $\mathrm{Ca}^{2+}$ mobilization in cat iris sphincter smooth muscle cells by cAMP-elevating agents. Cell Signal 9: 411-421, 1997. https://doi.org/10.1016/S0898-6568(97)00018-1

FAHRENKRUG J. Transmitter role of vasoactive intestinal peptide. Pharmacol Toxicol 72: 354-363, 1993. https://doi.org/10.1111/j.1600-0773.1993.tb01344.x

FARBER HW, LOSCALZO J. Pulmonary arterial hypertension. N Engl J Med 351: 1655-1665, 2004. https://doi.org/10.1056/NEJMra035488

FEDERICO A, MORGILLO F, TUSSILLO C, CIARDIELLO F, LOGUERCIO C: Chronic inflammation and oxidative stress in human carcinogenesis. Int J Cancer 121: 2381-2386, 2007. https://doi.org/10.1002/ijc.23192

FRANCIS SH, NOBLETT BD, TODD BW, WELLS JN, CORBIN JD: Relaxation of vascular and tracheal smooth muscle by cyclic nucleotide analogs that preferentially activate purified cGMP-dependent protein kinase. Mol Pharrnacol 34: 506-517, 1988.

GANZ P, SANDROCK AW, LANDIS SC, LEOPOLD J, Jr GIMBRONE MA, ALEXANDER RW: Vasoactive intestinal peptide: vasodilation and cyclic AMP generation. Am J Physiol 250: 755-760, 1986. https://doi.org/10.1152/ajpheart.1986.250.5.H755

GHATEI MA, TAKAHASHI K, SUZUKI Y, GARDINER J, JONES PM, BLOOM SR: Distribution, molecular characterization of pituitary adenylate cyclase-activating polypeptide and its precursor encoding messenger RNA in human and rat tissues. J Endocrinol 136: 159-166, 1993. https://doi.org/10.1677/joe.0.1360159

GIAID A, SALEH D: Reduced expression of endothelial nitric oxide synthase in the lungs of patients with pulmonary hypertension. N Engl J Med 333: 214-221, 1995. https://doi.org/10.1056/NEJM199507273330403

GIEMBYCZ MA, NEWTON R: Beyond the dogma: novel beta2-adrenoceptor signalling in the airways. Eur Respir J 27: 1286-1306, 2006. https://doi.org/10.1183/09031936.06.00112605

GOETZL EJ, SREEDHARAN SP, TRRCK CW, BRIDENBAUGH R, MALFROY B: Preferential cleavage of aminoand carboxylterminal oligopeptides from vasoactive intestinal polypeptide by human recombinant enkephalinase (neutral endopeptidase, EC 3.4.24.11). Biochem Biophys Res Commun 158: 850-854, 1989. https://doi.org/10.1016/0006-291X(89)92800-3

GOMARIZ RP, JUARRANZ Y, ABAD C, ARRANZ A, LECETA J, MARTINEZ C: VIP-PACAP system in immunity: New insights for multi target therapy. Ann NY Acad Sci 1070: 51-74, 2006. https://doi.org/10.1196/annals.1317.031

GRONEBERG DA, SPRINGER J, FISCHER A: Vasoactive intestinal polypeptide as mediator of asthma. Pulm Pharmacol Ther 14: 391-401, 2001. https://doi.org/10.1006/pupt.2001.0306

GUNST SS, STROPP JQ: Effect of $\mathrm{Na}+/ \mathrm{K}+$ adenosine triphosphatase activity on relaxation of canine tracheal smooth muscle. Appl Physiol 64: 635-641, 1988. https://doi.org/10.1152/jappl.1988.64.2.635

HAHM SH, EIDEN LE: Cis-regulatory elements controlling basal and inducible VIP gen transcription. Ann NY Acad Sci 865: 10-26, 1998. https://doi.org/10.1111/j.1749-6632.1998.tb11158.x

HALL IP. Second messengers, ion channels and pharmacology of airway smooth muscle. Eur Respir J 15: 1120-1127, 2000. https://doi.org/10.1034/j.1399-3003.2000.01523.x

HAMASAKI Y, MOJARAD M, SAID SI: Relaxant action of VIP on cat pulmonary artery: Comparison with acetyicholine, lsoproterenol \& PGEI. J Appl Physlol 54: 1607-1611, 1983. https://doi.org/10.1152/jappl.1983.54.6.1607 
HASHIMOTO H, NOGI H, MORI K, OHISHI H, SHIGEMOTO R, YAMAMOTO K, MATSUDA T, MIZUNO N, NAGATA S, BABA A: Distribution of the mRNA for a pituitary adenylate cyclase-activating polypeptide receptor in the rat brain: an in situ hybridization study. J Comp Neurol 371: 567-577, 1996a. https://doi.org/10.1002/(SICI)1096-9861(19960805)371:4<567::AID-CNE6>3.0.CO;2-2

HASHIMOTO H, YAMAMOTO K, HAGIGARA N, OGAWA N, NISHINO A, AINO H, NOGI, KIMANISHI H, MATSUDA T, BABA A: cDNA cloning of a mouse pituitary adenylate cyclase-activating polypeptide receptor. Biochim Biophys Acta. 1281: 129-133, 1996b. https://doi.org/10.1016/0005-2736(96)00056-9

HASHIMOTO H, ISHIHARA T, SHIGEMOTO R, MORI K, NAGATA S: Molecular cloning and tissue distribution of a receptor for pituitary adenylate cyclase-activating polypeptide. Neuron 11: 333-342, 1993. https://doi.org/10.1016/0896-6273(93)90188-W

HEDLUND P, ALM P, EKSTROM P, FAHRENKRUG J, HANNIBAL J, HEDLUND H, LARSSON B, ANDERSSON KE: Pituitary adenylate cyclase-activating polypeptide, helospectin, and vasoactive intestinal polypeptide in human corpus cavernosum. $\mathrm{Br} \mathrm{J}$ Pharmacol. 116: 2258-2266, 1995. https://doi.org/10.1111/j.1476-5381.1995.tb15062.x

HENNING RJ, SAWMILLER DR: Vasoactive intestinal peptide: cardiovascular effects. Cardiovasc Res 49: 27-37, 2001. https://doi.org/10.1016/S0008-6363(00)00229-7

HERSHENSON MB, WYLAM ME, PUNJABI N, UMANS JG, SCHUMACKER PT, MITCHELL RW, SOLWAY J: Exposure of immature rats to hyperoxia increases tracheal smooth muscle stress generation in vitro. J Appl Physiol 76: 743-749, 1994. https://doi.org/10.1152/jappl.1994.76.2.743

HOSOYA M, KIMURA C, OGI K, OHKUBO S, MIYAMOTO Y, KUGOH H, SHIMIZU M, ONDA H, OSHIMURA MARIMURA A, FUJINO M: Structure of the human pituitary adenylate cyclase activating polypeptide (PACAP) gene. Biochim Biophys Acta 1129: 199-206, 1992. https://doi.org/10.1016/0167-4781(92)90488-L

ISHIHARA T, SHIGEMOTO R, MORI K, TAKAHASHI K, NAGATA S: Functional expression and tissue distribution of a novel receptor for vasoactive intestinal polypeptide. Neuron 8: 811-819, 1992. https://doi.org/10.1016/0896-6273(92)90101-I

ITO T, IGARASHI H, PRADHAN TK, HOU W, MANTEY SA, TAYLOR JE, MURPHY WA, COY DH, JENSEN RT: GI side-effects of a possible therapeutic GRF analogue in monkeys are likely due to VIP receptor agonist activity. Peptides 22: 1139-1151, 2001. https://doi.org/10.1016/S0196-9781(01)00436-3

ITOH N, OBATA K, YANAIHARA N, OKAMOTO H: Human preprovasoactive intestinal polypeptide contains a novel PHI-27-like peptide, PHM-27. Nature 304: 547-549, 1983. https://doi.org/10.1038/304547a0

JOBE AH, BANCALARI E: Bronchopulmonary dysplasia. Am J Respir Crit Care Med 163: 1723-1729, 2001. https://doi.org/10.1164/ajrccm.163.7.2011060

JUARRANZ MG, SANTIAGO B, TORROBA M, GUTIERREZ-CANAS I, PALAO G, GALINDO M, ABAD C, MARTINEZ C, LECETA J, PABLOS JL, GOMARIZ RP: Vasoactive intestinal peptide modulates proinflammatory mediator synthesis in osteoarthritic and rheumatoid synovial cells. Rheumatology 43: 416422, 2004. https://doi.org/10.1093/rheumatology/keh061

KANAZAWA H, KAWAGUCHI T, FUJII T, SHOJI S, HIRATA K, KUDOH S, KURIHARA N, YOSHIKAWA J: Potentiation of the bronchoprotective effects of vasoactive intestinal peptide, isoprenaline, and theophylline against histamine challenge in anaesthetized guinea pigs by adrenomedullin. Thorax 51: 1199-1202, 1996. https://doi.org/10.1136/thx.51.12.1199

KUO KH, DAI J, SEOW CY, LEE CH, VAN BREEMEN C: Relationship between asynchronous Ca2+ waves and force development in intact smooth muscle bundles of the porcine trachea. Am J Physiol Lung Cell Mol Physiol 285: 1345-1353, 2003. https://doi.org/10.1152/ajplung.00043.2003

LABURTHE M, COUVINEAU A, MARIE JC: VPAC receptors for VIP and PACAP. Recept Channels 8: 137-153, 2002. https://doi.org/10.1080/10606820213680

LAMPERTI ED, ROSEN KM, VILLA-KOMAROFF L: Characterization of the gene and messages for vasoactive intestinal polypeptide (VIP) in rat and mouse. Brain Res Mol Brain Res 9: 217-231. 1991. https://doi.org/10.1016/0169-328X(91)90005-I

LASKIN DL, PENDINO KJ: Macrophages and inflammatory mediators in tissue injury. Ann Rev Pharmacol Toxicol 35: 655-677, 1995. https://doi.org/10.1146/annurev.pa.35.040195.003255 
LAU EMT, GIANNOULATOU E, CELERMAJER DS, HUMBERT M: Epidemiology and treatment of pulmonary arterial hypertension. Nat Rev Cardiol 14: 603-614, 2017. https://doi.org/10.1038/nrcardio.2017.84

LINDEN A, CARDELL LO, YOSHIHARA S, NADELL JA: Bronchodilation by pituitary adenylate cyclase-activating peptide and related peptides. Eur Respir J 14: 443-451, 1999. https://doi.org/10.1183/09031936.99.14244399

LI M, MADERDRUT JL, LERTORA JJ, BATUMAN V: Intravenous infusion of pituitary adenylate cyclase-activating polypeptide (PACAP) in a patient with multiple myeloma and myeloma kidney: a case study. Peptides 28: 1891-1895, 2007. https://doi.org/10.1016/j.peptides.2007.05.002

MAARMAN GJ, SCHULZ R, SLIWA K, SCHERMULY RT, LECOU S: Novel putative pharmacological therapies to protect the right ventricle in pulmonary hypertension: a review of current literature. $\mathrm{Br} \mathrm{J}$ Pharmacol 174: 497-511, 2017. https://doi.org/10.1111/bph.13721

MCGROGAN I, LU S, HIPWORTH S, SORMAZ L, ENG R, PREOCANIN D, DANIEL EE: Mechanisms of cyclic nucleotide-induced relaxation in canine tracheal smooth muscle. Am J Physiol 268: 407-413, 1995. https://doi.org/10.1152/ajplung.1995.268.3.L407

MENTLEIN R. Dipeptidyl-peptidase IV (CD26)-role in the inactivation of regulatory peptides. Regul Pept 85: 9-24, 1999. https://doi.org/10.1016/S0167-0115(99)00089-0

MIYAMOTO Y, HABATA Y, OHTAKI T, MASUDA Y, OGI K, ONDA H, FUJINO M: Cloning and expression of a complementary DNA encoding the bovine receptor for pituitary adenylate cyclase activating polypeptide (PACAP). Biochim Biophys Acta 1218: 297-307, 1994. https://doi.org/10.1016/0167-4781(94)90181-3

MIYATA A, JIANG L, DAHL RR, KITADA C, KUBO K, FUJINO M, MINAMINO N, ARIMURA A: Isolation of a neuropeptide corresponding to N-terminal 27 residues of pituitary adenylate cyclase activating polipeptide with 38 residues (PACAP38). Biochem Biophys Res Commun 170: 643-648, 1990. https://doi.org/10.1016/0006-291X(90)92140-U

MIYATA A, ARIMURA A, DAHL DH, MINAMINO N, UEHARA A, JIANG L, CULLER MD, COY DH: Isolation of a novel 38 residue hypothalamic polypeptide which stimulates adenylat cyclase in pituitary cells. Biochem Biophys Res Commun 164: 567-574, 1989. https://doi.org/10.1016/0006-291X(89)91757-9

MOLLER K, SUNDLER F: Expression of pituitary adenylate cyclase activating peptide (PACAP) and PACAP type I receptors in the rat adrenal medulla. Regul Pept 63: 129-139, 1996. https://doi.org/10.1016/01670115(96)00033-X

MUELLER E, VAN BREEMAN C: Role of intracellular $\mathrm{Ca}^{2+}$ sequestration in beta adrenergic relaxation of airway smooth muscle. Nature 281: 682-683, 1979. https://doi.org/10.1038/281682a0

NORTHWAY Jr WH, ROSAN RC, PORTER DY: Pulmonary disease following respiratory therapy of hyalinemembrane disease. Bronchopulmonary dysplasia. N Engl J Med 276: 357-368, 1967. https://doi.org/10.1056/NEJM196702162760701

NUTTLE LC, FARLEY JM: Frequency modulation of acetylcholine-induced oscillations in $\mathrm{Ca}^{2+}$ and $\mathrm{Ca}^{2+}$-activated Clcurrent by cAMP in tracheal smooth muscle. J Pharmacol Exp Ther 277: 753-760, 1996.

OGI K, MIYAMOTO Y, MASUDA Y, HABATA Y, HOSOYA M, OHTAKI T, MASUO Y, ONDA H, FUJINO M: Molecular cloning and functional expression of a cDNA encoding a human pituitary adenylate cyclaseactivating polypeptide receptor. Biochem Biophys Res Commun 196: 1511-1521, 1993. https://doi.org/10.1006/bbrc.1993.2423

PETKOV V, MOSGOELLER W, ZIESCHE R: Vasoactive intestinal peptide as new drug for treatment of primary pulmonary hipertension. J Clin Invest 111: 1339-1346, 2003. https://doi.org/10.1172/JCI17500

PISEGNA JR, WANK SA: Molecular cloning and functional expression of the pituitary adenylate cyclase-activating polypeptide type I receptor. Proc Natl Acad Sci USA. 90: 6345-6349, 1993. https://doi.org/10.1073/pnas.90.13.6345

PRAKASH YS, VAN DER HEIJDEN HF, KANNAN MS, SIECK GC: Effects of salbutamol on intracellular calcium oscillations in porcine airway smooth muscle. J Appl Physiol 82: 1836-1843, 1997. https://doi.org/10.1152/jappl.1997.82.6.1836

ROBINSON A, COLBRAN R: Calcium/Calmodulin-Dependent Protein Kinases. Encyclopedia of Biological Chemistry 2: 304-309, 2013. https://doi.org/10.1016/B978-0-12-378630-2.00493-X 
ROUX E, GUIBERT C, SAVINEAU JP, MARTHAN R: [Ca2+]i oscillations induced by muscarinic stimulation in airway smooth muscle cells: receptor subtypes and correlation with the mechanical activity. Br $\mathrm{J}$ Pharmacol 120: 1294-1301, 1997. https://doi.org/10.1038/sj.bjp.0701061

SAID SI, HAMIDI SA, DICKMAN KG, SZEMA AM, LYUBSKY S, LIN RZ, JIANG YP, CHEN JJ, WASCHE JA, KORT S: Moderate pulmonary arterial hypertension in male mice lacking the vasoactive intestinal peptide gene. Circulation 115: 1260-1268, 2007. https://doi.org/10.1161/CIRCULATIONAHA.106.681718

SAID SI: Vasoactive intestinal peptide. J Endocrinol Invest 9: 191-200, 1986. https://doi.org/10.1007/BF03348097

SAID SI: Vasoactive intestinal polypeptide: widespread distribution in normal gastrointestinal organs. Proceedings of the 57th Annual Meeting of the Endocrine Society, New York. 1975.

SHERWOOD NM, KRUECKI SL, MCRORY JE: The origin and function of the pituitary adenylate cyclase-activating polypeptide (PACAP)/glucagon superfamily. Endocr Rev 21: 619-670, 2000. https://doi.org/10.1210/edrv.21.6.0414

SHEWARD WJ, LUTZ EM, HARMAR AJ: The distribution of vasoactive intestinal peptide-2 receptor messenger RNA in the rat brain and pituitary gland as assessed by in situ hybridization. Neuroscience 67: 409-418, 1995. https://doi.org/10.1016/0306-4522(95)00048-N

SHIODA S, SHUTO Y, SOMOGYVARI-VIGH A, LEGRADI G, ONDA H, COY DH, NAKAJO S, ARIMURA A: Localization and gene expression of the receptor for pituitary adenylate cyclase-activating polypeptide in the rat brain. Neurosci Res 28: 345-354, 1997. https://doi.org/10.1016/S0168-0102(97)00065-5

SOMLYO AP, SOMLYO AV: Signal transduction and regulation in smooth muscle. Nature 372: 231-236, 1994. https://doi.org/10.1038/372231a0

SOPI RB, ZAIDI SIA, MLADENOV M, SAHITI H, ISTREFI Z, GJORGOSKI I, LAJCI A, JAKUPAJ M: L-citrulline supplementation reverses the impaired airway relaxation in neonatal rats exposed to hyperoxia. Respir Res 13: 68, 2012. https://doi.org/10.1186/1465-9921-13-68

SREEDHARAN SP, HUANG JX, CHEUNG MC, GOETZL EJ: Structure, expression, and chromosomal localization of the type I human vasoactive intestinal peptide receptor gene. Proc Natl Acad Sci USA 92: 2939-2943, 1995. https://doi.org/10.1073/pnas.92.7.2939

STAMENKOVSKA M, THACI Q, HADZIPETRUSHEV N, ANGELOVSKI M, BOGD-ANOV J, RECICA S, KRYEZIU I, GAGOV H, MITROKHIN V, KAMKIN A, SCHUBERT R, MLADENOV M, SOPI RB: Curcumin analogs (B2BrBC and C66) supplementation attenuates airway hyperreactivity and promote airway relaxation in neonatal rats exposed to hyperoxia. Physiol Rep 8: e14555, 2020. https://doi.org/10.14814/phy2.14555

SVOBODA M, TASTENOY M, CICCARELLI E, STIEVENART M, CHRISTOPHE J: Cloning of a splice variant of the pituitary adenylate cyclase-activating polypeptide (PACAP) type I receptor. Biochem Biophys Res Commun 195: 881-888, 1993. https://doi.org/10.1006/bbrc.1993.2127

TATEMOTO K, MUTT V: Isolation and characterization of the intestinal peptide porcine PHI (PHI-27), a new member of the glucagon-secretin family. Proc Natl Acad Sci USA 78: 6603-6607, 1981. https://doi.org/10.1073/pnas.78.11.6603

TREPICCHIO W, BOZZA M, PEDNEAULT G, DORNER A: Recombinant human IL-11 attenuates the inflammatory response through down-regulation of proinflammatory cytokine release and nitric oxide production. J Immunol 157: 3627-3634, 1996.

TSUNAWAKI S, SPORN M, DING A, NATHAN CF: Deactivation of macrophages by transforming growth factor. Nature 334: 260-262, 1988. https://doi.org/10.1038/334260a0

TUNCEL N, TORE F, SAHINTURK V, AK D, TUNCEL M: Vasoactive intestinal peptide inhibits degranulation and changes granular content of mast cells: A potential therapeutic strategy in controlling septic shock. Peptides 21: 81-89, 2000. https://doi.org/10.1016/S0196-9781(99)00177-1

ULRICH CD, HOLTMANN M, MILLER LJ: Secretin and vasoactive intestinal peptide receptors: members of a unique family of G protein coupled receptors. Gastroenterology 114: 382-397, 1998. https://doi.org/10.1016/S0016$\underline{5085(98) 70491-3}$ 
UMETSU Y, TENNO T, GODA N, SHIRAKAWA M, IKEGAMI T, HIROAKI H: Structural difference of vasoactive intestinal peptide in two distinct membrane-mimicking environments. Biochim Biophys Acta 1814: 724-730, 2011. https://doi.org/10.1016/j.bbapap.2011.03.009

USDIN TB, BONNER TI, MEZEY E: Two receptors for vasoactive intestinal polypeptide with similar specificity and $\begin{array}{lllll}\text { complementary } & \text { distributions. } & \text { Endocrinology } & 135 \text { : }\end{array}$ https://doi.org/10.1210/endo.135.6.7988457

WEI Y, MOJSOV S: Tissue specific expression of different human receptor types for pituitary adenylate cyclase activating polypeptide and vasoactive intestinal polypeptide: implications for their role in human physiology. J Neuroendocrinol 8: 811-817, 1996. https://doi.org/10.1046/j.1365-2826.1996.05191.x

WEIHE E, REMECKE M: Peptidergic innervation of the mammalian sinus nodes: vasoactive intestinal polypeptlde, neurotensin, substance P. Neuro Sci Lett 26: 283-288, 1981. https://doi.org/10.1016/0304-3940(81)90146-4

YANG CM, HSU MC, TSAO HL, CHIU CT, ONG R, HSIEH JT, FAN LW: Effect of cAMP elevating agents on carbachol-induced phosphoinositide hydrolysis and calcium mobilization in cultured canine tracheal smooth muscle cells. Cell Calcium 19: 243-254, 1996. https://doi.org/10.1016/S0143-4160(96)90025-1

YIANGOU Y, DI MARZO V, SPOKES RA, PANICO M, MORRIS HR, BLOOM SR: Isolation, characterization, and pharmacological actions of peptide histidine valine 42, a novel prepro-vasoactive intestinal peptide-derived peptide. J Biol Chem 262: 14010-14013, 1987.

ZOBAN P: Optimal oxygen saturation in extremely premature neonates. Physiol Res 68: 171-178, 2019. https://doi.org/10.33549/physiolres.933987 